\title{
Destruction of Irish manuscripts and the National Board of Education
}

\author{
RICHARD SHARPE \\ (Faculty of History, Oxford)
}

\begin{abstract}
BL MS Add. 40767 is a nineteenth-century copy of Richard Plunket's 'Rugadh Pádraig', thrown out with other manuscripts by its owner's descendants in 1899 and rescued by a visitor from Liverpool, who showed four fragments to Kuno Meyer. Meyer wrote to Douglas Hyde, and Hyde wrote to the newspapers, using the episode to castigate the board of intermediate education, which he blamed for the ignorance of Irish language and literature that lay behind such destruction. He was much engaged in an argument over Irish in schools, but here he brings the preservation of modern vernacular manuscripts into the discussion. He shows himself well aware of the important collections in the Royal Irish Academy, but he is at the same time critical of the Academy, whether in line with external prejudice or in the hope of inducing greater effort. Saving manuscripts was not high on the agenda of the Gaelic League, and, though Hyde was himself a collector, he offered no remedy for the loss of manuscripts other than a revival of the use of Irish.
\end{abstract}

Reports of the destruction of Irish manuscripts in the late nineteenth and early twentieth centuries surface from time to time. ${ }^{1}$ Such reports usually reflect the distance between the perceptions of middle-class commentators and those of the heirs who found themselves in possession of their fathers' or grandfathers' vernacular books, for which they had no use. If those heirs had seen any means to dispose of them for hard cash, we may be sure that fewer books would have been destroyed. Without their knowing that these old papers had a value to some people - people with money and opinions - they treated them with indifference. The processes by which manuscripts have ceased to exist have been much discussed,

\footnotetext{
${ }^{*}$ My thanks to Professor Liam Mac Mathúna for helpful comments on the draft of this paper.

1 'Destruction of Irish MSS' appears as a heading in Irish Book Lover 18 (1930), 30, where we read how eight volumes, comprising some four hundred songs, written by Art Mac Cubhthaigh and Peadar Ó Doirnín, both eighteenth-century scribes, which had turned up in an auction of furniture near Castleblayney (Co. Monaghan) 'had been given to the children as play-toys and had been torn to pieces'. This bears comparison with something Douglas Hyde said to the commission on intermediate education in 1899: a friend of Hyde's on that occasion rescued one of the manuscripts (below, n. 41).
} 
and the tendency has been to seek someone to blame. In almost all cases this is just wrong. There is no inherent reason why manuscripts should be kept after they have ceased to be useful to their owners. This is no less true of the superseded papyrus rolls that carried to destruction so much of the literature of Greece and Rome in the fourth and fifth centuries than of the vernacular books on paper once kept by teachers and farmers in nineteenth-century Ireland. This paper will show Douglas Hyde's reaction to one report of destruction, turned to political advantage as part of his campaign for more positive action by the board of education to encourage the study of Irish. The campaigning voice is shrill, tending to disguise Hyde's own interest in collecting vernacular manuscripts.

Mrs C, whose identity and location were not reported - Co. Cavan or Co. Meath is suspected - had thrown out a basketful of Irish manuscripts in 1899, when clearing the loft of her house, so that the family might move upstairs and the main rooms might be rented out to a visitor from Liverpool who enjoyed fishing the local river. Returning one day from riverbank to house, the angler found some manuscript fragments and took them home with him. Back in Liverpool, he showed them to Dr Kuno Meyer, lecturer in Celtic at the University College there. Meyer would become closely linked to the nationalist language movement in Ireland and the key figure in launching the School of Irish Learning in 1903. Although there is little sign that he had any active interest in modern manuscripts, he associated this living story with the long-held notion that the Vikings had destroyed the manuscripts of the Old Irish period, in which he was deeply interested. He wrote to Dr Douglas Hyde, who as president of the Gaelic League since 1893 had given a new impetus to the campaign for the Irish language, at that period felt to be critically endangered. The two men were already in contact with one another. Meyer's letter came into Hyde's hands at what was for him a timely moment in 1900. It would have been still more opportune if it had reached him in the spring of 1899, when the Palles Commission, as it is sometimes known, was considering the future of the role of Irish in secondary schools. This had been a hot topic then, and Hyde was not one to let it fade from memory. He sent Meyer's letter to the newspapers with a covering letter of his own, in which he pointed the finger of blame for Mrs C's action: 'The National Board is guilty', he wrote, in capitals. Since these appeared in at least two newspapers on the same date, Meyer's letter must have been copied, but we may hazard that the actual letter ended up with a newspaper editor rather than in Hyde's archive.

There are three topics here that merit some discussion. First, the connexion between Kuno Meyer and Douglas Hyde was clearly key to this story's publication. This journal has recently published what is known to survive from Meyer's letters to Hyde, ranging in date from 1896 to Meyer's death in 1919. ${ }^{2}$ It is unfortunate Hyde's papers were scattered. When he died in 1949, the republic of which he

2 D. Ó Cróinín, 'Letters of Kuno Meyer to Douglas Hyde, 1896-1919', Studia Hibernica 42 (2016), $1-64$. 
was the first president had no policy towards the papers of its statesmen, and the Hyde family simply disposed of everything except his Irish manuscripts, which he bequeathed to the university in Galway. ${ }^{3}$ By 1900 he was already an important figure in the language movement and he occupies a distinctive niche in the history of Irish literature. Hyde sought to exploit Meyer's letter in the context of the very public debate over the future of Irish in intermediate education. This is essential background to the letter and to our second topic. Hyde was absolutely central to stirring up this issue, a public debate that is better remembered by those interested in Irish than by historians of education. Third, stories about the destruction of manuscripts deserve to be collected as a testimony to loss, but they are the more interesting when manuscripts are described in sufficient detail for us to take them into account alongside surviving books. In this case, however, all is not lost. We have no idea how many manuscripts Paddy flung into the river, but the four fragments found by the angler were kept by him and put up for auction in 1923 .

The heading to Meyer's letter, 'Wholesale destruction of Irish manuscripts', taking up Hyde's expression, was clearly exaggerated. It may have influenced some like-minded readers. In the Gaelic Journal, for example, in May 1901, as a comment on six leaves of a small paper manuscript found by a roadside, we read, 'There has been wholesale destruction of MS in Counties Meath and Louth. What a dreadful crime against nationality and literature is this ignorant vandalism. ${ }^{4}$ It is no use railing now, and there would have been better courses of action then. What we can do now is to study collectors of manuscripts, who transferred them into environments where they were and are still valued. Learning their methods and their sources is a route back to the context in which manuscripts were made and used.

This double letter appeared in the Freeman's Journal, Wednesday, 5 September 1900, p. 2 cols. 7 and 8, written, edited and submitted by Douglas Hyde. On the same day, it was printed in the Irish Daily Independent and Daily Nation, p. 6 cols. 3 and 4. The Independent provides more elaborate headings: 'Irish Manuscripts - Important Letter from Dr Douglas Hyde - The National Board's Action - Trinity College and the Royal Irish Academy. To the Editor, Independent and Nation'. In the latter Hyde is named in the signature first as An Craoibhín Aoibhinn and then as Douglas Hyde.

\footnotetext{
${ }^{3}$ Janet Egleson Dunleavy and Gareth W. Dunleavy, Douglas Hyde: a maker of modern Ireland (Berkeley, CA, 1991), 435-36. Some libraries hold copies of the fifty-seven-page Catalogue of the library of Dr Douglas Hyde (Decd) for auction at 'Ratra', Phoenix Park, Dublin on 10th October, 1949, and following days ([Dublin: E. Maguire], 1949). No papers were included in the auction, but the Dunleavys say that his correspondence and papers 'were similarly disposed of'. They make no mention of the vernacular manuscripts (on which see below, n. 59).

${ }^{4}$ Gaelic Journal, May 1901, 88. The magazine had been taken over by the Gaelic League under Hyde's presidency in 1893; from 1899 its editor was Seosamh Laoide. My thanks to Uáitéar Mac Gearailt for this example.
} 


\title{
DESTRUCTION OF IRISH MANUSCRIPTS
}

\section{LETTER FROM DR DOUGLAS HYDE}

\author{
To the Editor, "Freeman's Journal."
}

Dear Sir, I enclose you a most interesting and important communication from $\mathrm{Dr}$ Kuno Meyer. It proves that the wholesale destruction of Irish manuscripts that has followed the teaching of our National curse, the National Board, has not yet been checked, even by the example and wide-spread ramifications of the Gaelic League. That such an atrocity as the Liverpool gentleman describes could have taken place six years ago I did not doubt, but after all that we have done and are doing to save a remnant of our country's heritage, I confess it is a disappointment in the extreme to see that the party of light and culture in Ireland can have their efforts still paralysed by the people of darkness and ignorance who control the National Board.

If in the elementary books of that Board there had been even a paragraph to the effect that the Irish nation had a great language and literature of their own, which the people should be proud of, should preserve, and should reverence, does anyone think that it would be possible to find to-day a young school-made savage to fling a basketful of Irish manuscripts into the river $<$ ? $>$ How proud Archbishop Whately would have been could he have seen this grand consummation of his teaching. ${ }^{5}$ How delighted Doctors Atkinson, Fitzgerald, Mahaffy, and the rest of the anti-Irishmen will be when they read it. For it is their teaching that has prevailed and not ours. It is not we. It is Trinity College that has conquered and not the Gaelic League.

The drowning of these precious relics is a crime in the eyes of Europe, a crime in the eyes of universal scholarship, aye, and, I may add, it cannot but be a crime in the eyes of heaven. Who is guilty of the responsibility? The answer is

\section{THE NATIONAL BOARD IS GUILTY.}

It is they, and they alone, who have warped and poisoned the mind of peasant Ireland. It is they who have not only rendered such outrages possible, but have carefully prepared the way for them, led up to them by long teaching, and, no doubt, the majority of the Board glory in their execution, because they are at heart politicians and not educationalists, and direct their hundreds of thousands of pounds

\footnotetext{
${ }^{5}$ Archbishop Richard Whately, who was the Church of Ireland archbishop of Dublin from 1831 until his death in 1863 , was a key figure in the early days of the national board of education: 'Whately had a profound influence on the development of the national school system, acting in effect as chairman of the board that administered the system. He also wrote many of the texts that were used in Irish schools, and later adopted for schools in England and elsewhere. His influence was so significant that he has been termed "the head schoolmaster of the Irish people".' (B. MacMahon, Eccentric Archbishop: Richard Whately of Redesdale (Stillorgan, 2005), quoted in History Ireland 13:2 (Mar.-Apr. 2005), 12). Douglas Hyde treated his influence as negative in his statement to the royal commission on Irish University Education, made 10 June 1902 (Royal Commission on University Education in Ireland, Appendix to the Third Report (C 1229), Minutes of Evidence, QQ. 9190-92, p. 331a).
} 
every year to the political object of rendering it impossible for anyone to speak henceforth of Ireland a Nation.

Kuno Meyer's note and the letter of the Liverpool gentleman speak for themselves. The great German scholar adds in a private letter to me-'I wish you could see these manuscripts, so carefully and neatly written. ${ }^{6}$ I think these facts ought to be circulated widely. It is well known that the Royal Irish Academy will spend no money upon preserving the manuscripts of the last century, and that if a peasant were to offer to sell them a complete copy of, say, Raftery's poems (which the Gaelic League have been striving for years to collect together), they would not give five shillings for it. Dr Atkinson instead of preserving to the nation all the MSS which come into the market with the money confided by the Government to the Royal Irish Academy for Irish studies prefers to spend it in employing German clerks to work at a philological dictionary which may not see the light for 20 or 30 years, whilst, in the meantime, poems and manuscripts of the last 150 years are spurned from the door of the Academy as things of no value. When they are all destroyed, then Dr Mahaffy and Dr Atkinson, and Dr Fitzgerald, and Trinity College in general will turn round upon Ireland and say-'Your native language has produced no poet and no literature for the last 150 years.' Dr Atkinson's policy with regard to the literature is notorious. He said publicly on February 22nd, 1899, 'My advice to parents throughout Ireland would be never to let your children be brought into contact with this literature.' ${ }^{7}$ This is also the policy of the Trinity College professors who apparently control the National Board. They are aiming at the complete extinction of the modern language, while Trinity College in the Academy and the others co-operate with them in accomplishing the destruction of the modern literature. A well-known second-hand bookseller in Dublin assured me that as many as 200 Irish MSS had passed through his hands during the last few years. These have been dispersed again to the four winds of heaven, chiefly America and Australia. All are now practically lost to the nation, and not one did the Royal Irish Academy purchase. Finding they would buy nothing modern, he said that for years back he had ceased offering them anything.

There does still, however, in spite of all indirect efforts to destroy them, exist a great quantity of modern manuscripts scattered through the country. Our enemies, the stupid party in Ireland, would hail with joy the extinction of these volumes. We must not gratify them. We must see to it that no more basketfuls of Irish manuscripts are chucked into rivers by educated [sic], I might almost say, ad hoc, by the National Board. The fullest possible publicity should be given to these facts

\footnotetext{
${ }^{6}$ This letter has not been traced. Hyde implies that Meyer's letter here was not private but sent to him with a view to publication.

${ }^{7}$ Quoted by Hyde, 'A university scandal', The New Ireland Review 12 (1899-1900), 193-204 (p. 200n, in a footnote to a comic parody), and again when the same was reprinted as a pamphlet, $A$ University Scandal, Gaelic League Pamphlets No. 7 [Dublin, 1900], 5n. Hyde cited the words from the press report in Daily Express, 23 Feb. 1899.
} 
as the best means of putting an end to them. The day is rapidly approaching when every modern Irish manuscript will be a thing of value.

With apologies for this long letter, yours truly, Douglas HydE.

\section{Wholesale Destruction of Irish Manuscripts By Dr Kuno Meyer}

A famous and often quoted passage in the Cogadh Gaedhel re Gallaibh tells us that during the whole period of the Viking invasion of Ireland the foreign marauders never ceased to destroy the manuscript books preserved in the libraries of the monasteries, by either burning them or throwing them into the water: do loisgeadh 7 do báidhedh a sgreptra 7 a liubhair in gach cill $>$ in gach neimhedh ina robhadar la dibergachaibh ó thosach go deiredh. ${ }^{8}$

It is certain that this deliberate proceeding on the part of the Norse invaders largely explains the fact that of so many thousands of manuscripts - both Latin and Irish - as must have existed in the Irish libraries of the 9th and 10th centuries, so few only have come down to us. ${ }^{9}$ Still there can be no doubt that in more modern times also much has been lost through the negligence and ignorance of the Irish themselves. I have heard Dr Whitley Stokes say, on the authority, I think, of Petrie, that a Dublin jeweller had confessed to having consigned to the melting pot about $£ 70,000$ worth of gold ornaments which, during a period of forty years, had found their way to him; ${ }^{10}$ and the story of the ignorant young priest of Cong, who cut up

\footnotetext{
${ }^{8}$ Meyer refers to the early twelfth-century text Cogad Gaedel re Gallaib, § 80, ed. J. H. Todd, Rolls Series 48 (London, 1867), 138. The context is after Brian Bórama had pacified Ireland and held 'a great royal visitation' (mórcuairt ríg); the author says that Brian sent scholars and teachers to teach and to buy books from overseas to replace those destroyed by the Scandinavians, all part of a programme of public works during his fifteen years' rule as king of Ireland. The story is implicitly concerned with Latin books that could be brought from overseas and not, as Meyer wished to convey, with Irish literary manuscripts. Máire Ní Mhaonaigh has discussed the passage as transferring to Brian the support for the church's aspirations shown by his descendant, Muirchertach Ua Briain $(d$. 1119): 'The date of Cogad Gáedel re Gallaib', Peritia 9 (1995), 354-77, at 374-75.

${ }^{9}$ A different view is offered in my paper, 'Books from Ireland, fifth to ninth centuries', Peritia 21 (2010), 1-55.

${ }^{10} \mathrm{I}$ have not found any secure basis for this story. If Whitley Stokes had heard it from Petrie, then we should date that contact to before Stokes left for India in 1862. Petrie died in 1866. In his memoir of Petrie, Sir William Stokes (Whitley's father) quoted Petrie as referring to the jeweller who bought a medieval gold crown and displayed it in his shop window (The life and labours in art and archaeology of George Petrie (London, 1868), 270). The decades before 1860 were the great period of the Academy's collecting Irish metalwork under Petrie's guidance. None the less, references to the melting pot are not rare in nineteenth-century Irish archaeological journals, but there was also some tendency to exaggerate. The first issue of an archaeological journal in Ireland, for example, had large numbers in mind: 'Unless we teach our peasantry that the gold or silver coin or ornament, which he turns up from beneath the surface of the earth, possesses a value above the market-price of the metal, thousands of such articles, instead of enriching our national collections of antiquities, will yearly find their way into the melting-pot' (Transactions of the Kilkenny Archaeological Society 1 (1849), 99). An interesting example concerns a penannular brooch in gold, found at Clonmel, which went to a dealer in William Street, Dublin, who paid £3 8s. per ounce (Journal of the
} 
ancient illuminated manuscripts to adorn his breviary is well known. ${ }^{11}$ But I was not prepared to learn that such acts of vandalism were going on in Ireland at the present day, and that there were men and women now to imitate the Vikings, and throw whole boxfuls of manuscripts, the collection of their own fathers, into the water! The following is a brief account of such a deplorable act of vandalism which has lately come under my notice.

A few weeks ago a Liverpool gentleman, Mr John G. Gilbert, came to me with the tattered and soiled fragments of four different Irish manuscripts, neatly and carefully written during the latter part of the last century. In a statement which he drew up at my request he gives the following account of the circumstances under which he found them. For certain reasons he suppresses the name of the village and neighbourhood where he made his find.

(Here follows Mr Gilbert's narrative. I have omitted his account of what brought him for the first time to Ireland, but the following is the conclusion of his narrative. From what he says in the first part of his story I think that it happened in or near the county Meath. - Douglas Hyde.)

'Arrived at the river, I asked at an old cottage where a tiny patch is washed by the stream if I might leave my luncheon basket. "By all manes, sir, and welcome," was the response, and by the close of the day my second hostess had secured a promise that I would come and stay to fish the river from her house the following year, and so in May twelve months ago [1899] I again had a happy week under her roof. For such an advent, of course, preparations had to be made, and it had been decided shortly before my coming to "clear the loft," a room running over the two living rooms on the ground floor, for the family sleeping accommodation, and in which, amongst other old-world things, I had been shown on my first visit the spinning-wheel still used to spin the natural, undyed wool, from which the family stockings, etc., are still knit.

'Coming from fishing through Mrs C.'s plot on my first day, I picked out of the long grass the wet and tattered remains of a book, and loose leaves most carefully

Kilkenny and South-East of Ireland Archaeological Society new ser. 2 (1859), 353, 444-46, which reprints a letter on the subject from Dr William Wilde to the Freeman's Journal, 2 Nov. 1859). The North Mooghaun Hoard, found in Co. Clare in 1854 amounted to more than 175 ounces, and most of the finds were melted down. It would have taken many such hoards in the hands of one jeweller to achieve $£ 70,000$, which is not credible. I have wondered whether Meyer may have confused stories about the melting down of gold Claddagh rings, left with pawnbrokers by Irish emigrants at the time of the Famine: 'Huge numbers of Claddagh rings were left with a Mr [John] Kirwan [pawnbroker, Galway] following the Great Famine 1846/7 which finally had to be consigned to the melting pot as there was nobody to redeem or purchase them' (W. Dillon, 'The Claddagh Ring', Galway Archaeological Society Journal 4 (1905-6), 11-16). Even so, Dillon thought the sums advanced against them amounted to around $£ 500$, but we are not told what the gold realised.

${ }^{11}$ Petrie was himself the source of this story, quoted from his (untraced) journal of 1821 by Stokes, Life and Labours, 284, and discussed by R. Sharpe, 'Medieval manuscripts found at Bonamargy and other hidden manuscripts', Studia Hibernica 41 (2015), 49-85 at 74-77. 
written in characters and language entirely unknown to me. Feeling they were of interest, I asked Mrs C. if she had more, what they were, and how they came to be where I found them? "Sure they were a lot of old Irish writings my father had" (he was a schoolmaster 60 years ago). "We cleared out the loft, and Paddy threw them in the river beyant." And so perished a clothes-basket full of old Irish MSS-less the portion I secured - of unknown value to Irish studies, the life-long collection of a highly intelligent man.'

Let these extraordinary facts speak for themselves; I will only add a very short account of the contents of the manuscripts which Mr Gilbert has recovered.

There are altogether the remains of four separate manuscripts. No. 1 is of unique interest and value as containing a modern, word-for-word paraphrase of the two most celebrated Old Irish hymns - that of Fiacc on St Patrick and of Broccan on St Brigit. The former, beginning in old Irish 'Génair Pátraic in Nemthur', is thus rendered:-
Rugadh Padruig a Nemthur
mar a dearbhtar ansna starradh
do bhi na macoimh sé mbliadhan deug
an tan do tugadh a mbruid daoirse é, etc.

The hymn on Brigit (Ni car Brigit buadach bith) -

Nior ghradhaig Brighid bhuadhach an saoghal

do shuidheadh mur eun ar uaigneas a ndiaidh a háil

do codladh an naomh mar bhean bhraide

ag eugnach bas a heinmhic, etc.

Though even from these short quotations it is apparent that the modern translator understood the original but imperfectly, yet the interest remains of an Irish version made more than a thousand years after the original was composed.

The second manuscript is in a deplorable state of dilapidation; still, there are remains of 23 leaves. Their contents are of great variety. Among other things there are fragments of the tale entitled 'Cethearnach Ui Dhomhnaill', edited by O'Grady, in 'Silva Gadelica,' and of that witty and humorous story, 'Ceisniomh inghine Ghuil,' of which I edited an old Irish version in 'Hibernica Minora.' There is a copy of O'Daly's satire on Dr Whaley, and a number of other poems-historical and religious - which I have as yet not been able fully to decipher.

A third manuscript contains a large number of well-known Munster songs, as well as a curious version of the 'Wearing of the Green.' Lastly, there is a very neatly-written fragment of a theological tract on death (air an mbás) beginning 'Creud é an nídh an bás? As é is bás ann, sgaramhuin shiorruidhe le n-uile nidh saoghalta,' etc. I hope to give a fuller account of this interesting find in one of the Continental periodicals devoted to Irish studies.

KUNO MEYER. University College, Liverpool. 
First, then, Meyer's contact with Douglas Hyde appears to have been initiated by Hyde, who in 1896 asked Meyer for a letter of support when he applied for the chair of Irish at Trinity College in succession to James Goodman. ${ }^{12}$ Goodman died in January, and the chair was advertised within a few weeks. Hyde may have mentioned Robert Atkinson in his letter to Meyer, whose reply, dated 18 March, referred to him, 'Surely, the electors will not allow themselves to be influenced entirely by Dr Atkinson. ${ }^{13}$ Provost Salmon was against Hyde, and the chair went to James Murphy. ${ }^{14}$ It may be thought that this set up a confrontation between the Gaelic League and the college. The next surviving letter was written in response to Hyde's request for a statement on the value of Irish language and literature in secondary schools to rebut what Dr John Pentland Mahaffy, of Trinity College, had said to the board of intermediate education, sitting as a commission appointed by the lord lieutenant. ${ }^{15}$ Meyer was one of a number of European scholars approached who provided such letters. The next letter known is that presented here. Meyer, it may be presumed, had had little personal contact with Hyde, but they were well aware of one another's published work. Over succeeding years their letters show an increasing warmth of friendship.

Second, that Intermediate Education (Ireland) Commission, which began to take evidence in 1898, looms very large in Hyde's activities at this time. It has rated a brief mention in work on the history of education in Ireland, not such that would make one suppose it was of any great importance. ${ }^{16}$ This is definitely not the perspective of those concerned with the Irish language. Writing after 1927, the Irish historian Father Paul Walsh referred to 'an Intermediate Commissionthe famous one, <before > which Mahaffy, Atkinson, and Edward Gwynn-now provost of Trinity College—appeared with small credit to themselves'. ${ }^{17}$ Hyde,

${ }^{12}$ National Library of Ireland (NLI), MS 18262 comprises typed testimonials for Hyde for the Trinity chair in 1896 from Kuno Meyer, Georges Dottin, Standish James O'Grady, Joseph Loth and Fr Walter Conway, PP, Cararoe, as well as two hand-written letters from John Rhys and W. Macneile Dixon for the Cork chair in 1905. Meyer says nothing of any personal acquaintance. This survives in a small clutch of Hyde's papers, MSS 18252-65. There are more letters to Hyde among the papers of Conradh na Gaeilge, NLI MSS 21098, 21099.

${ }^{13}$ Ó Cróinín, 'Kuno Meyer's letters', 14 (no. 1).

${ }^{14}$ Douglas Hyde, Mise agus an Connradh (go dti 1905) (Dublin, 1937), 58-60; Dunleavy and Dunleavy, Douglas Hyde, 200-01, refer to testimonials from Edward Gwynn and William Lecky, both of Trinity, as well as those mentioned in $\mathrm{n} .12$ above, but they give no references: Risteárd Ó Glaisne, Dúbhglas de hÍde (1860-1949): ceannródaí cultúrtha 1860-1910 (Dublin, 1991), 143-45.

${ }^{15}$ Ó Cróinín, 'Kuno Meyer's letters', 14-15 (no. 2), a personal letter sent along with his statement to the commission (no. 3), which was intended for publication.

${ }^{16}$ Most informative on the period is T. J. McElligott, Secondary education in Ireland 1870-1921 (Blackrock, 1981); see also John Coolahan, Irish education: history and structure (Dublin, 1981), 65-67; John Coolahan, 'Imperialism and the Irish national school system' in J. A. Mangan (ed.), Benefits bestowed?: education and British imperialism (Manchester, 1988), 76-93 at 83; D. H. Akenson, 'Pre-university education, 1870-1921' in W. E. Vaughan (ed.), A New History of Ireland vi: Ireland under the Union, 1870-1921 (Oxford, 1989), 523-38 at 525-26.

${ }^{17}$ Quoted from notes on a list of his own books, made by Walsh, in this case with reference to Professor John Rhys (1840-1915) of Jesus College, Oxford, whom Walsh took to have been a member 
Walsh noted, 'smashed the Trinity people'. The fame of the commission largely resulted from the efforts of Douglas Hyde to discredit those witnesses who spoke against teaching the Irish language and to make this known as widely as possible. It has merited an article and a few pages in a number of modern works. ${ }^{18}$ The board spent around $£ 85,000$ per year on intermediate education - a great deal less than Hyde represented - and its policies, as established in 1878, had come in for criticism. The lord lieutenant of Ireland, Earl Cadogan, had appointed the then current members of the board of education to serve as commissioners. These were Chief Baron Christopher Palles (1831-1920), a judge, as chairman; Mr Justice Dodgson Hamilton Madden (1840-1928), also a judge; the mathematician turned New Testament scholar George Salmon (1819-1904), DD, provost of Trinity College; Charles O'Conor (1838-1906), the O'Conor Don, a veteran of the Society for the Preservation of the Irish Language, who as an MP had helped to get 'Celtic language and literature' included in the intermediate curriculum in 1878 and had served on the intermediate board ever since; ${ }^{19} \mathrm{Revd}$ William Todd Martin (1837-1915), DD, a Presbyterian divine from Ulster; David Graham Barkley (1836-1903), from Maghera (Co. Londonderry), who had served as a judge in India in the 1880s; and the Most Revd William Joseph Walsh (1841-1921), [RC] Archbishop of Dublin, who had long taken an interest in Irish-language education and had been a long-term friend of the chairman Palles. Palles is the only one whose role as a board member and commissioner features in their brief biographies in the Dictionary of Irish Biography (2004). They published two reports and a large volume of evidence, both written answers to questions and transcripts of interviews, which are still available to

of the commission, 'the only man on the commission able to speak a few words of Irish to Dr Douglas Hyde' (N. Ó Muraíle, Prince of Irish historians: Fr Paul Walsh (1885-1941), tireless researcher; versatile, innovative scholar, Paul Walsh Memorial Lecture 1 (Maynooth, 2016), 38-39). Rhys was neither a member of nor a witness before the commission on intermediate education (n. 20); a letter from him was quoted to Hyde (QQ. 9303-6) and to Atkinson (Q. 12346), and by Hyde in his memorandum (p. 83), but it was not printed in the appendix. (Archbishop Walsh cited an Irish phrase to Hyde, Q. 9349.) Nor did Edward Gwynn appear before the commission, but his views were discussed, and he had submitted written answers to published questions. Here he had said, 'The presence of Celtic in the examinations is a positive evil. Special inducements are held out to smatterers', who took the option for the sake of easy marks. He came in for criticism from Hyde, and Meyer treats him as not keeping up with progress in early Irish studies (Ó Cróinín, 'Kuno Meyer's letters', 18, no. 6). Father Walsh must have known that Rhys was a member of the commission on university education in Ireland in 1901-02 (n. 5), though no word of Irish appears in his questions put to Hyde (Minutes of Evidence, QQ. 9220-24).

${ }^{18}$ P. J. Mathews, 'Hyde's first stand: the Irish language controversy of 1899', Eire-Ireland 35:1-2 (Spring/Summer 2000), 173-87; see also Donncha Ó Súilleabháin, Cath na Gaeilge sa Chóras Oideachais, 1893-1911 (Dublin, 1988), 28-33; Dunleavy and Dunleavy, Douglas Hyde, 210-11; Ó Glaisne, Dúbhglas de hÍde (1860-1949), 233-49; Seán Ó Lúing, Kuno Meyer 1858-1919: a biography (Dublin, 1991), 15-18; Ó Cróinín, 'Kuno Meyer's letters', 5-8. Such matters did not engage, for example, Timothy G. McMahon, Grand opportunity: the Gaelic Revival and Irish society, 1893-1910 (Syracuse, NY, 2008).

${ }^{19}$ McElligott, Secondary education in Ireland, 37-38, 154. 
read. ${ }^{20}$ On the commission, Provost Salmon was someone whom Hyde had long regarded as hostile to him and his nationalist views. J. P. Mahaffy, fellow of Trinity, had published his views in November 1898 and sent copies of the article to Palles and Madden. ${ }^{21}$ The commissioners held interviews on twenty-five days between 11 January and 23 February 1899, and Mahaffy was among the first to give his evidence. ${ }^{22}$ Mahaffy had his prejudices, and, like Hyde, he was not shy of publicity. ${ }^{23}$ Hyde called the evidence 'a long-drawn scoff', but it was his invoking the name of Robert Atkinson, professor of Romance languages and also of Sanskrit at Trinity, who had done sterling work on Irish texts, that became a sensation. Among much else he said (on the authority of Dr Atkinson), 'that where Irish literature is not religious it was silly, and where it was not silly it was indecent'. Hyde made the remark famous. ${ }^{24}$ The point was made in relation to the difficulty in setting prescribed texts for study. ${ }^{25}$ Atkinson

${ }^{20}$ Commission on intermediate education (Ireland) 1899, 1st Report with Appendix, including Answers to Questions (C 9116, C 9117), House of Commons 1899 xxii; Final Report (C 9511), House of Commons 1899 xxii, Evidence (C 9512, C 9513), HC 1899 xxiii, xxiv. Coolahan, Irish education, says that the report was available in August 1899. It led to the Intermediate Education (Ireland) Amendment Act 1900. These papers are now available on line through Enhanced British Parliamentary Papers on Ireland, www.dippam.ac.uk/eppi, or by subscription from ProQuest UK Parliamentary Papers.

${ }^{21}$ J. P. Mahaffy, 'How to circumvent "cramming" in Irish secondary education', The Nineteenth Century. A monthly review 44, no. 261 (Nov. 1898), 867-80. He saw Irish as useless and sought its removal as an option from the curriculum: 'The subject is paraded every year to please a few enthusiasts, who are at best only sentimental, at worst actively maintaining what separation they can between Ireland and Great Britain' (pp 872, 876). This led to a reply by Father L. Healey, 'Professor Mahaffy on intermediate education', Irish Ecclesiastical Record 4th ser. 4:12 (Dec. 1898), 420-60.

${ }^{22}$ His interview on 12 January was lengthy and wide-ranging: Minutes of Evidence, QQ. 614-927. It was reported in the Freeman's Journal, 13 Jan. 1899, 7. The reprint in Gaelic League Pamphlets No. 12 (n. 24) selected only four short but pertinent sequences.

${ }^{23}$ W. B. Stanford and R. B. McDowell, Mahaffy: a biography of an Anglo-Irishman (London, 1971), 104-12, provide a well-informed but poorly referenced discussion. I have been unable to follow up their citing an interview with Mahaffy in the Daily Express on 16 February, two days after Hyde's evidence to the Commission, with a reply from Hyde in the next issue.

${ }^{24}$ The pithy wording is Hyde's own, 'A university scandal' (n. 7), 196, again drawing on the Daily Express. It will be found quoted often, including in a debate in Dáil Éireann, 20 March 1929. Mahaffy's own words were not so succinct (Minutes of Evidence, Q. 655; The Irish language and Irish intermediate education II Evidence of Dr Mahaffy, Dr Delany SJ, Father Devitt SJ, Dr Bernard, and Father Daly, Gaelic League Pamphlets No. 12 [Dublin, 1901], 2). The chairman put the point to Atkinson himself (Minutes of Evidence, QQ. 12381-91), who responded with oblique reference to a filthy and degrading book, generally taken to be O'Grady's Silva Gadelica (1892). The chairman reminded Atkinson that he had read Aristophanes, an Athenian playwright much given to comic obscenity. Atkinson modified his position: 'I have said again and again that it is not very frequently gross and hardly ever licentious, but it is low down to the soil. There is an absence of any elevating ideal, and there is always the chance of coming to something that will give a modern man a shock from its crude realism': The Irish language and Irish intermediate education IV Dr Atkinson's Evidence, Gaelic League Pamphlets No. 14 [Dublin, 1901], 13-14.

${ }^{25}$ In his examiner's report from 1898 , Hyde had commented that no candidate had attempted to answer from one of two prescribed texts, 'Keating's difficult Three shafts of death, all without 
himself was interviewed at short notice towards the end of proceedings. He was exposed as holding inconsistent and absurd views, ridiculed for errors in his knowledge of the language, and within a year or two had had his reputation destroyed. ${ }^{26}$ Hyde himself, who had served as national examiner in 'Celtic' in 1897 and 1898, had submitted written answers. ${ }^{27} \mathrm{He}$ was interviewed on 14 February 1899, and his appearance in front of the commission was trailed with a laudatory piece in that morning's Freeman's Journal. ${ }^{28} \mathrm{He}$ began his answers by saying, 'I must premise that the Gaelic League is an organisation which is a teaching body, and engaged in doing voluntarily teaching work that the Government has not done. ${ }^{29}$ By this time he had written to scholars in Germany, France and England with an interest in Irish or Welsh languages, most of them, it may be said, noted for their work on the older periods of Irish and not for its contemporary use, and he submitted their answers as evidence, having himself translated those sent in German or French. Kuno Meyer, of course, was one of them, and some of these letters make heartening reading. ${ }^{30}$ The final report was silent on the subject of Irish, apparently neutral between the

exception preferring the less formidable alternative book' (Report of the intermediate education board for Ireland 1898 (C 9294), House of Commons 1899, xxii, 44). Robert Atkinson had prepared the edition of Keating's Three shafts himself. The alternative was O'Grady's edition of Tóruigheacht Dhiarmada agus Ghráinne, reprinted for the Society for the Preservation of the Irish Language in two parts (Dublin, 1880-81) (M. Ó Murchú, Cumann Buan-Choimeádta na Gaeilge: tús an athréimnithe (Dublin, 2001), 254-56). From it the prescribed text was Part 1, omitting §§ 23-25. When the edition was reprinted for the Society by R. J. O’Duffy (1884), twelve lines of the translation (§ 23, p. 28) were replaced with asterisks. A few bolder lines in $\S 50$ (p. 48) were so treated in both printings. Hyde mentions in his memorandum (n. 30), 81, 'The Pursuit of Diarmuid and Gráinne is objected to as unfit for children', adding, 'because this contains a passage which, after all, is not nearly as bad as a child will get in even Horace.' He explains, 'This book was put on the course in the paucity of texts which existed when Irish was placed on the Intermediate programme'; by 1899 substitution would be easy. Some people, it seems, were still scandalised by this text fifty years later (reflected in an editorial comment by 'Aithirne' [David Greene], Comhar 7:1 (Ean. 1948), 8, with my thanks to Mícheál Hoyne).

${ }^{26}$ David Greene, 'Robert Atkinson and Irish studies', Hermathena 102 (Spring 1966), 6-15; Tomás Ó Fiaich, 'The great controversy' in S. Ó Tuama (ed.), The Gaelic League idea (Cork, 1972), 63-75 at 68-69. Atkinson's election as president of the Royal Irish Academy from 1901 was in some quarters seen as ill-judged side-taking.

${ }^{27}$ The argument was frequently made to the commission that Celtic should be replaced with Irish in the board's examinations.

28 'The Irish language', Freeman's Journal, 14 Feb. 1899, p. 4 cols. 7-8. This already quoted from several of the letters of foreign scholars.

${ }^{29}$ Minutes of Evidence, Q. 9196; reprinted in Irish language and Irish intermediate education III Dr Hyde's Evidence, Gaelic League Pamphlets No. 13 [Dublin,1901], 1.

${ }^{30}$ Published as part of Appendix XIII to the evidence, 61-86, where there is also a memorandum written by Hyde himself. The writers were Owen Edwards (Oxford), himself a campaigner for the status of Welsh in schools, Alfred Nutt (London), E. C. Stern (Berlin), Ernst Windisch (Leipzig), Georges Dottin (Rennes), Heinrich Zimmer (Greifswald), who signed off in Irish, Frederick York Powell (Oxford), Kuno Meyer (Liverpool), Holger Pedersen (Copenhagen), and Eleanor Hull (London). Powell, Dottin and Zimmer also sent follow-up letters after the hearings. 
contending positions. ${ }^{31}$ Mahaffy brought out another article in August 1899, focusing on the language question. ${ }^{32}$ In December 1899 Hyde published an article in New Ireland Review, 'A University Scandal', which he subsequently circulated 'in pamphlet form', which was soon reprinted as Gaelic League Pamphlets No. 7 , sold for 1d, and distributed through branches of the League. ${ }^{33}$ The letters from continental scholars were all set out here. Hyde's letter above mentions George Fitzgerald, a physicist and a fellow of Trinity, who was interviewed, and who, after the commission had reported, was appointed to serve on the intermediate board; he was concerned to introduce a practical component to education. Mahaffy too was appointed to the board. Recording these appointments as 'the only answer made to the demands of the nation', Hyde, in this pamphlet says that this 'looks like a studied insult to the Irish people'. The next pamphlet, Bilingual Education, was based on an address by Archbishop Walsh, a member of the board, delivered to students at Our Lady of Mercy Training College, Baggot Street, on 7 December 1900, and released for publication ten days later. Under the heading 'A Voice from Trinity College', the appendix in this pamphlet presented Dr Barkley's interaction with Dr Atkinson, 'Just one point. You know Irish is still a spoken language in some parts of the country?' 'Yes.' Atkinson was led to speak in favour of Irish in schools where it was the first language of the children. Archbishop Walsh pursued him, getting him to voice two inconsistent positions, that the Irish language was to go, and yet it was to be used in schools where it was spoken 'vernacularly'. ${ }^{34}$ Hyde followed up these pamphlets with ten others, each entitled The Irish language and Irish intermediate education, in which he reprinted a good deal of the evidence given on the question, including his own. ${ }^{35}$ The reprinting of these pamphlets meant that in some cases ten thousand

${ }^{31}$ McElligott, Secondary education in Ireland, 154-55, refers to 'an intemperate attack' on Irish by Mahaffy and Atkinson, 'splendidly defended by Douglas Hyde'. He goes on: 'The revival movement failed to influence the Commissioners in any way', but, despite their neutral stance the number taking Irish for examination rose sharply.

32 J. P. Mahaffy, 'The recent fuss about the Irish language', The Nineteenth Century. A monthly review 46, no. 270 (Aug. 1899), 213-22. He admitted that the dispute had 'galvanized life into the well-nigh extinct study of the spoken tongue' (p. 213).

${ }^{33}$ The first pamphlet was published in 1899 in Dublin by the Eblana Press [copy in NLI Ir $37841 \mathrm{~h}$ 9]. The League's pamphlet followed in 1900. Branches were able to buy these pamphlets at 9d. per dozen, $5 \mathrm{~s}$. per hundred, post free, implying that they were distributed in considerable numbers.

${ }^{34}$ Minutes of Evidence, QQ. 12424-31, reprinted in W. J. Walsh, Bilingual education, Gaelic League Pamphlets No. 8 (Dublin, 1900), 22. Archbishop Walsh's role in this commission and his interest in the language are passed over by his biographers: P. J. Walsh, William J. Walsh, Archbishop of Dublin (Dublin, 1928), and Thomas J. Morrissey, William J. Walsh, Archbishop of Dublin, 1841-1921: no uncertain voice (Dublin, 2000), 178.

35 These are Gaelic League Pamphlets Nos. 11-20, produced early in 1901. A review of them appeared in the Daily Express, which argued that the foreign testimonies showed only the importance of Irish for advanced education; this drew forth a riposte from Father Michael P. O'Hickey, Freeman's Journal, 7 May 1901, p. 6, to the effect that Meyer and others were quotably concerned with secondary education. The review provides evidence for the date of publication. They may be read in the set of thirty-four pamphlets in the Royal Irish Academy, RRG/25/G/Box 1. The National Library holds 
copies were distributed, and the Gaelic League was winning the argument. ${ }^{36}$ It has been judged the first occasion when the League garnered widespread public support. ${ }^{37}$ This was also reflected in a rapid rise in demand for its elementary booklets and in the take-up of Irish in the intermediate examinations. ${ }^{38}$ At the beginning of 1902 Kuno Meyer's appointment by the intermediate board as examiner in Celtic appears to have been a less conspicuous result of Hyde's discreet influence; it was not uncontroversial, causing 'heated discussion' in the Irish-language press. ${ }^{39}$

Alongside all this activity by the League, Hyde himself was also able to use the newspapers to good effect. Here, in September 1900, in the middle of the argument, he does just that with Kuno Meyer's letter.

In his evidence to the commission, responding to a question from the O'Conor Don about the extent of Irish literature, Hyde had made a remark about the loss of manuscripts but also about the number and interest of the manuscripts held by the Royal Irish Academy: ${ }^{40}$

Owing to the disgusting irreverence for the past that the Irish have been guilty of, of which I have already spoken, that large literature has suffered immensely from the destruction of manuscripts. In County Clare, a friend of mine went into a cabin, and found children destroying manuscripts on the floor. In one he found a story called 'The Affection of Dubhlocha for Mongan' - for which the libraries of Europe had been searched through in vain, and which was afterwards discovered in the Yellow Book of Lecan - a single copy of it. It was printed from that, and it was edited with all the care and skill that two such world-renowned

most of the set, and Trinity College has these ten and a number of others. These ten were digitised in Toronto for the Internet Archive.

${ }^{36}$ Tony Crowley, Wars of words: the politics of language in Ireland 1537-2004 (Oxford, 2005), 142-44. 'The belief was', he writes, 'that, since the colonial education system had contributed to the plight of the Irish language in the past, then for the Gaelic League the very same system must be made to support its revival. The stress on education as the chief means of preserving the language was to have important consequences in the twentieth century.' Coolahan writes of the 'the popular, if erroneous, belief that it was the policy of the board which was mainly responsible for the decline of Irish' ('Imperialism and the Irish national school system', 84).

${ }^{37}$ Ó Fiaich, 'The great controversy', 69.

${ }^{38}$ Ó Murchú, Cumann Buan-Choimeádta na Gaeilge, 248, shows a massive peak in the sale of An Cheud Leabhar Ghaeilge in 1901, sustained for the two following years, before it was superseded. McElligott, Secondary education in Ireland, 155, contrasts examination entries in 1879 and 1921.

${ }^{39}$ Discussed by Ó Lúing, Kuno Meyer, 17-18, who goes so far as to express sympathy for Atkinson and Mahaffy, who 'had no notion of what a subtle antagonist they were facing in Douglas Hyde'. Meyer to Hyde, 7 Feb. 1902 (Ó Cróinín, 21, no. 8); Hyde to Meyer, n.d., 'Of course I knew all about your appointment and can tell you the whole story of it when I see you' (Ó Lúing, 17-18); Meyer to Hyde, 20 Feb. 1902, 'My appointment will not do your cause any harm' (Ó Cróinín, 21-22, no. 9).

${ }^{40}$ Minutes of Evidence, Q. 9206; reprinted in Irish language and Irish intermediate education III Dr Hyde's Evidence, Gaelic League Pamphlets No. 13 [Dublin, 1901], 12. 
scholars as Mr Nutt and Dr Kuno Meyer were able to bestow upon it; and they consider it to be one of the most valuable texts in existence, as casting light on the anthropological views of early Ireland. If that single MS had been lost, then my MS would have been unique. ${ }^{41}$ It was over 100 years old. That tearing up of MSS, and the want of interest in their own past, has enormously affected the amount of modern Irish literature, though I should think there is still in manuscript enough of Irish written within the last 200 years to fill a couple of hundred octavo volumes. It is very hard to know what we have and what we have not. There is nobody to delve in this mine; there is no money set apart in Ireland for anybody who will do the work; it must be done by volunteers. I know that the Royal Irish Academy catalogued about one-half of the MSS in it, and the catalogue was contained in thirteen volumes, and fills 3,448 pages; and from looking over that catalogue, and comparing it as well as I could, I came to the conclusion that about 10,000 pieces must have been catalogued, varying from, perhaps, a single verse of song up to a long epic. ${ }^{42}$

The second part of the statement goes some way to undermine the first. The loss of a copy of this text, whichever was in Hyde's mind, may have been culturally significant, but it was probably not textually important. A clear and rational census of the literature in its manuscript context has still not been achieved. Hyde was seeking to make his point without a good example to hand.

${ }^{41}$ The passage is difficult to follow. The late medieval tale Serc Duibe Locha do Mongán was printed by K. Meyer in The Voyage of Bran son of Febal (London, 1895), i, 58-84, from the so-called Book of Fermoy, a copy written in the fifteenth century, with an English translation. Douglas Hyde owned a manuscript copy of this work, written by Seán Mac Mathghamhna, Co. Clare, 1811, now NUI Galway, MS de hİde 13, 240-61, from which the tale was printed by Séamas Ó Duilearga, 'Tóruigheacht Duibhe Lacha Láimh-ghile (aliter Serc Duibhe-Lacha do Mongán)', Zeitschrift für celtische Philologie 17 (1928), 347-70. From Hyde's own note at the front there, we learn that this manuscript was rescued from the children and given to him in 1899 by his friend Dr George Unthank MacNamara (1849-1919) of Corofin, Co. Clare. Hyde did not verify his references. The book inaccurately known as the Yellow Book of Lecan, Trinity College Dublin, MS 1318 (H. 2. 16), cols. 911-14, was used to print several older tales of Mongán, Voyage of Bran, i, 42-58, but in every case other early manuscripts were available and used in the edition; these texts have been re-edited by Nora White, Compert Mongáin and three other early Mongán tales (Maynooth, 2006). Hyde had the information available to show that no text was entirely lost. He resisted the temptation to criticise Atkinson's work on the Yellow Book, something Meyer referred to in a letter dated 10 March 1903, 'in der Campagne gegen Trinity College' (Ó Cróinín, 'Kuno Meyer's letters', 28-29, no. 17).

${ }^{42}$ There is no obvious set of thirteen volumes forming the old catalogue. While the general index, made in 1869, occupies thirteen volumes (Royal Irish Academy, MS 67 F 4-13, 67 G 1-3), this has only 1666 pages. The catalogues on which it was based do not amount to thirteen volumes, but all told the mid-nineteenth-century catalogues are fifteen volumes. Hyde was no doubt making a point in his caption to the portrait at the front of his edition of Raftery's poems (n. 45), 'in one of the many uncatalogued MSS in the Royal Irish Academy, marked 23/09' (the shelfmark should be read as 23 O 9). 
In another context, instead of talking down the prevailing attitude to Irish manuscripts, he was willing to emphasise the widespread survival of vernacular written culture, even on the eve of the founding of the Gaelic League. This was a note added to his evidence given to the royal commission on university education in Ireland, when he was interviewed on 10 June 1902:43

Even when Irish scholarship was at its lowest, which was, perhaps, shortly before the founding of the Gaelic League, there were many fine local scholars with good collections of Irish MSS to be found here and there through the country. The race of Scribes was never quite extinct. Even when the fortunes of the Irish Language were at their lowest, many hundreds of roofs would have had to fall in before a knowledge of the literary language could have been extinguished. Some counties have good Irish scholars in almost every parish.

This is nearly as much an overstatement as his negative position. He had no evidence of 'good collections of Irish manuscripts' here and there around the country in the hands of local scholars as late as (say) 1890. Caches of unused manuscripts existed and were at risk of loss. What Hyde knew or thought was the real state of affairs does not come across in such statements. He was before these commissions to make a point, the point was not always the same, and in this case he wanted to emphasise that an Irish university could build on a native learned tradition that was not extinct. In such public arguments a scholar may be allowed to adopt a campaigning voice.

Hyde was not entirely fair to Mrs $\mathrm{C}$ in what he wrote to the newspapers about her destruction of manuscripts, but the cause was too important for niceties. 'The wholesale destruction of Irish manuscripts that has followed the teaching of our National curse, the National Board' was certainly happening as much before the establishment of the board and for reasons not created by the board. ${ }^{44}$ The Gaelic League, with its many branches, was encouraging the use of Irish but made no public pronouncements about conserving modern manuscripts. Its quest for a set of the poems of Raftery, Antoine Ó Reachtabhra, was in reality Hyde's own quest, pursued in Co. Galway and in the library of the Academy. ${ }^{45}$ Whether Mrs C or

\footnotetext{
${ }^{43}$ Commission on Irish University Education (n. 5), Minutes of Evidence, Q. 9259, added note (p. 317). Relevant selections from the evidence were reprinted as Irish in University education. Evidence given before The Royal Commission on University Education, Gaelic League Pamphlets No. 29 (1902).

${ }_{44}$ This relates also to a point made by Edward Gwynn to the effect that knowledge of Irish was less in 1899, twenty-one years after the setting up of the intermediate board, than it had been twenty years before. The board was not responsible for that decline, which had set in much earlier and was steepest between 1841 and 1861 (B. Ó Cuív, Irish dialects and Irish-speaking districts (Dublin, 1951), 22-27). These were probably also the two decades that saw most loss of late manuscripts and the fastest transfer into the protection of the Royal Irish Academy.

${ }^{45}$ Dunleavy and Dunleavy, Douglas Hyde, 204-05. He would later publish Abhráin atá leagtha ar an Reachtúire, or, Songs ascribed to Raftery (Dublin, 1903), which began as articles in the Weekly
} 
Paddy was his target as 'a school-made savage', it was unfair to use such language, albeit against the national board rather than those educated in its schools. To call 'the drowning of these precious relics' 'a crime in the eyes of Europe, a crime in the eyes of universal scholarship', and indeed 'a crime in the eyes of heaven' is a wild exaggeration, but it leads him into a few remarks about the status of Irish manuscripts at the time. How true these are it is difficult to test. He was also critical of a perceived policy of the Royal Irish Academy, which had been the principal preserver of Irish manuscripts for close to seventy years. It is a point on which the Academy was defensive. ${ }^{46}$ It continued to receive manuscripts, though it had not made any major purchases since the auction of Bishop William Reeves's books in 1892. Thirty-two manuscripts were bought for the Academy on that occasion at a cost of $£ 126$ by Robert Atkinson and Maxwell Close. Writing in 1894, Hyde mentions a discovery he made, 'the other day when examining the Reeves collection', and he chose to remember Close's role: ${ }^{47}$

On the lamented death of that great scholar they were put up to auction, when the Royal Irish Academy bought 32 of the volumes, the rest being unfortunately scattered again to the four winds of heaven. For his exertions and generosity in securing even so many of these MSS, especially those which at first sight looked least important, but which

Freeman. On his search, see pp 8-13. He used RIA, MS 23 O 9 (cat. 64), but he appears not to have found RIA, MS 23 O 42 (cat. 63), written in 1835 by Patrick Glynn. Both had been bought by the Academy at the sale of James Hardiman's library (1856 Hardiman 559, 567). They were not catalogued or indexed when Hyde was searching. What Hyde refers to as Mr Glynn's book is now NLI, MS G 751, written in 1891 by his friend John Glynn (1843-1915), town clerk of Tuam, a lifelong promoter of Irish in the Tuam News. This he borrowed, but he did not use another manuscript of Glynn's, now NLI, MS G 752. The modern edition by Ciarán Ó Coigligh, Raiftearaí: amhráin agus dánta (Dublin, 1987), 195-202, shows the textual importance of these manuscripts: 23 O 9 (with twenty-five poems), 23 O 42 (the same poems and two extra, 10 and 13), while G 751 (thirty-six poems), though missing some from the other witnesses, adds a further sixteen poems.

${ }^{46}$ The prejudiced view of the Academy's position increased between 1900 and 1920, and in 1922, when a new national institution was talked of, Edward Gywnn drafted several pages on Irish learning and the Academy's contribution, which were included in a statement read by the president of the Academy, Sydney Young FRS, 16 March 1922. With reference to Irish manuscripts, he said that, although the number and value of Irish manuscripts offered for sale had decreased, while competition had increased, 'the Academy has always been ready to buy when an opportunity has offered': 'A statement made by the President at the Annual Meeting, March 16, 1922' [Best, § 2346; copy in RIA], 1-6, at p. 3.

${ }^{47}$ Douglas Hyde, The story of early Gaelic literature (London, 1895), 91n. Close had written a strong reference in Hyde's favour in 1891 (Dunleavy and Dunleavy, Douglas Hyde, 175). He had been active in the Society for the Preservation of the Irish Language, and he was an early member of the Gaelic League, providing it with important financial support. Hyde later referred to him as 'mo chara' (Mise agus an Connradh, 83), but he was apt to embrace many acquaintances in his friendship. After Close's death on 13 Sept. 1903, an obituary notice in Celtia 3:6 (July-Aug. 1903), 107 , refers to this episode, travestying the facts by making Close buy the manuscripts personally when the Academy had refused to do so; Hyde's words are echoed, 'while the others were allowed to go with the stream scattered by the four winds of heaven'. 
contained treasures of folk-lore and folk-song, the Hon. Treasurer, Rev. Maxwell Close, has placed Irish-speaking Ireland under yet another debt of gratitude to him. It is not always that which is most ancient which is also most valuable from either a literary or a national stand-point, nor is a manuscript necessarily valueless because it has no philological importance.

That was published in 1895 . Four years later the same wording appeared in another work with an extended conclusion: ${ }^{48}$

It is not always that which is most ancient which is most valuable from a literary or a national point of view. The pity of it is that any Irish MS that comes into the market should not be bought up for the nation with the money assigned by the Government and confided to the Royal Irish Academy for Irish studies, unless a special search should show that the Academy already possesses a copy of each piece in it. I am convinced that many hundreds or thousands of pieces have been through neglect to do this irreparably lost to the nation. Oh the pity of it!

Hyde had been a member of the Academy since 1890, though how closely he was involved I cannot now say. The catalogues to which he referred were incomplete, but he knew the extent of the collection. The identification of individual 'pieces' remains something to be carried out, but the preservation of one copy is not an appropriate yardstick for deciding whether another manuscript was worth buying. It is certainly not the case that those manuscripts sold to other bidders in the Reeves sale were shunned by Atkinson and Close as too new, and their purchases contradict Hyde's assertion that 'poems and manuscripts of the last 150 years are spurned'. ${ }^{49}$ Hyde's hostility to the Irish Dictionary, towards which the government directed a substantial amount of money through the Academy, was hostility to its salaried editor, none other than Atkinson, and his focus on the older language rather than the modern one. ${ }^{50}$ It was in 1896 that Atkinson had proposed to recruit students from

\footnotetext{
${ }^{48}$ Douglas Hyde, A literary history of Ireland from the earliest times to the present day (London, 1899), 376n.

${ }^{49}$ Copies of the sale catalogue can be studied in the library of the Royal Irish Academy and in the National Library: Catalogue of the valuable library of the late Right Rev. William Reeves, DD, Lord Bishop of Down, Connor, \& Dromore, President of the Royal Irish Academy, \&c., comprising select biblical literature $[\ldots]$ and an important collection of Irish manuscripts on vellum and paper $[\ldots$ ], to be sold by auction by John W. Sullivan [ . . ] 21st November, and four following days (Dublin, 1892). The section on Irish manuscripts (lots 811-66) will be included with commentary in my forthcoming work on Irish Manuscript Sales.

${ }^{50}$ Atkinson served as editor from 1880 to 1907 , when he was (briefly) succeeded by Meyer. 'Nothing appeared during those twenty-seven years except some elegant but hardly adequate sample page-proofs' (E. G. Quin, 'Irish studies', The Royal Irish Academy: a bicentennial history 1785-1985 (Dublin, 1985), 166-87, p. 182). Greene, 'Robert Atkinson and Irish studies', 9, tells us that 'the
} 
Leipzig to assist in the work. ${ }^{51}$ Whether Hyde's reported conversation with a Dublin bookseller took place is now impossible to say, and whether the bookseller spoke truly is another matter again. The idea that two hundred Irish manuscripts were sold by a Dublin dealer to buyers in North America and Australia is not supported by any evidence. The Academy did not cease to acquire Irish manuscripts during the later 1890s and beyond. None the less a few words in the newspapers might encourage them to do more.

Meyer's letter had provided Hyde with an opportunity to present his views on these matters, and he seized it. The eloquence of his opening paragraphs did not address material questions concerning manuscripts. No more had the Gaelic League during those six years since 1893, 'after all we had done and are doing'. Hyde was himself acquiring manuscripts, and he may have equated that with the League's action. It would be difficult to show that his letter in the papers made any difference.

Meyer's own view is also inclined to exaggeration. Quoting from Cogad Gaedel re Gallaib, he looks back nine hundred years to little purpose before conceding 'the negligence and ignorance of the Irish themselves'. Even in 'modern times', the examples he provides, at least half a century old, are themselves doubtful. The tale of the young curate of Cong is one recorded by Petrie as far back as 1821, when it was already twenty years or more in the past, and it comes without good credentials. The destruction of gold ornaments or any other archaeological finds in precious metal had always happened, just as fine household silverware had often been melted down and the metal reused in the eighteenth and early nineteenth

nationalist press protested bitterly against this policy and pointed out that Atkinson was getting a salary of $£ 300$ a year for working on a dictionary which no one would ever see'. The newspaper articles were very likely written by Douglas Hyde. Meyer expressed his views on Atkinson's work in letters to R. I. Best in 1906-07, quoted by Ó Lúing, Kuno Meyer, 81, 91.

${ }^{51}$ RIA, Irish MSS Committee Minutes, 9 May 1894, shows Atkinson's regretting 'that he has no hope whatever of securing competent assistants of the kind required [to excerpt quotations from texts in the manuscript facsimiles] in Ireland' (iii, 326). On 13 May 1896 he was allowed $£ 300$ 'to procure assistance', but on 11 Nov. 1896 'he had failed to secure assistance' (iii, 340, 341). I am grateful to Dáibhí Ó Cróinín for bringing to my attention a revealing letter from Atkinson to Ernst Windisch, dated at Wildbad im Schwarzwald, 17 July 1896: 'I want to ask if among your students there could be found one or two, who would be willing to come over to Dublin for a year (or perhaps two years) to assist me in copying and transcribing. I do not require any great labour from them, as the hours (in the Academy) would be from 10 to 4, nor would the work be of so elaborate a kind as to need advanced knowledge in Irish, so that relatively younger men would serve the purpose excellently. The salary is $150 £$ per annum, i.e. practically fifteen pounds per month, as there are only ten months, two being holiday-time. I should be very much obliged, if you could aid me in this matter, as my eyes and hands are not what they were, and I am thereby compelled to supplement them by means of others. It is unfortunately quite useless my endeavouring to get assistance from the material at my disposition in Ireland, as Irish study is prosecuted, if at all, merely as a popular subject and with a serious ignorance of the enormous difficulties of the subject as well as the necessity of special training therein' (Universitätsarchiv Leipzig, Nachlaß Windisch, 2. 1. 12. 1). Academy records show no evidence for German clerks among Atkinson's assistants, but his approach to Windisch must have been talked about. 
centuries. Bemoaning such vandalism avoided asking what was happening to find and save manuscripts.

When we come to the actual circumstances that have given rise to all this posturing, we are given the words of the gentleman from Liverpool who was the occasion of the destruction of these manuscripts and at the same time the rescuer of a few fragments. John G. Gilbert cannot be identified with confidence. The UK Census 1901 shows two men of that name living in Liverpool (among sixteen named John Gilbert). The more likely person is probably John G. Gilbert, aged 53, whose occupation was given as Stock Share Broker, but the possibility cannot be excluded that it was John G. Gilbert, aged 52, Grocer and Wine Merchant. The leisure and means to take fishing holidays in Ireland, Gilbert's having access to Dr Meyer in the college, and his keeping the Irish books he found until 1923, when they were sold through Sotheby's, may point to the stockbroker rather than the grocer, but we have not the evidence to judge the grocer's prosperity. Meyer's brief descriptions are useful, but they are complemented by the entries in Sotheby's sale catalogue. The items appear as two lots under the heading Other Properties (p. 70) in a miscellaneous sale, 25-27 June 1923:

[749] Irish ManUSCRIPT. 121/2 pp. 8vo. unbound. The Hymns of Fiacc on St Patrick and of Broccan on St Brigit, a word for word paraphrase of the two most celebrated Irish hymns. XVIII cent.

Described by Dr Kuno Meyer in the Irish Independent, Sept 5, 1900 (a copy of which accompanies the lot), as being of unique interest and value; it was found by the present owner, with the manuscripts in the next lot, at a cottage where he was staying for fishing.

This is the first of the four as described by Meyer. It was bought for 12/- by Quaritch, acting for the British Museum, where it is now BL MS Add. 40767. ${ }^{52}$ Behind the modern Irish paraphrases Meyer recognised the Old Irish poems, Génair Pátraicc and Ni car Brigit, which had been for two hundred years the most accessible and recognised specimens of Old Irish-between their publication in Father John Colgan's Trias Thaumaturga (Louvain, 1647) and the publication of the Old Irish glosses by Johann Kaspar Zeuss in Grammatica Celtica (1853). Neither Meyer nor Robin Flower, curator of manuscripts at the Museum and dedicated student of Irish, were able to recognise that the paraphrases were the work of Richard Plunket, probably a schoolmaster, from Co. Meath, which appear in manuscript with the date 1784 and were printed in $1791 .{ }^{53}$ This copy is somewhat later than

${ }^{52}$ S. H. O'Grady and Robin Flower, Catalogue of Irish manuscripts in the British Museum (London, [1889-92]-1953), ii, 437-38. Buyer and price from the hammer copy of the sale catalogue in the British Library.

${ }^{53}$ Richard Sharpe, 'Richard Plunket (fl. 1772-1791), "a neglected genius of the county of Meath", Riocht na Midhe 28 (2017), 191-203. 
that. With the few pages were found (it seems) four leaves from a book of accounts, dealing with payments in March 1873 to a handful of workmen on the Headfort estate for work on the Edenburt-Enagh drain in Co. Cavan on the north side of the River Blackwater. This is the only indication we have that may point to where the manuscripts were found. It must be supposed that they were with the unbound leaves of manuscript and they are now together in a Museum binding. Also within the binding is a cutting from the Irish Daily Independent, preserving Meyer's letter but not Hyde's. ${ }^{54}$ The other fragments were treated as a single lot.

[750] IRISH MANUSCRIPTS, one very dilapidated, 10 leaves, 4to, another dated March 5, 1816, of Songs or Poems, portions translated into Latin script, 24pp. 4to, and a portion of a printed book, $8 \mathrm{vo}$, also referred to by Dr Kuno Meyer, loc. cit. (3)

The auction catalogue marks this lot as 'passed', signifying that no one bid. Meyer referred to the second item as 'in a deplorable state of dilapidation', but he mentioned twenty-three leaves; by 1923, thirteen of those were perhaps too far gone to be worth keeping. He identified three works, Cethearnach Ui Dhomhnaill, citing O'Grady's edition;" 'that witty and humorous story', Ceisniomh inghine Guil, of which he had himself printed a version; ${ }^{56}$ and what he calls 'O'Daly's satire on Dr Whaley', a poem from c. 1691, which John O'Donovan had printed in his edition of the Elizabethan satire on Ireland attributed to Aonghus na nAor Ó Dálaigh. ${ }^{57}$ Together with other poems, 'historical and religious', it is possible that this fragment in bad condition was perhaps as much as two hundred years old when thrown out. Next, the booklet of poems or songs has a scribal date, 5 March 1816, which will confirm its identification if it can be found, and Meyer tells us that the songs were from Munster 'as well as a curious version of the Wearing of the Green'. Finally, the sale catalogue mentions only a fragment from a printed book, where Meyer saw

\footnotetext{
${ }^{54}$ Noted by P. de Brún, 'Cnuasaigh de lámhscríbhinní Gaeilge: treoirliosta', Studia Hibernica 7 (1967), 146-81 at 174 n. 22.

${ }^{55}$ An Ceithearnach Caoilriabhach, ed. S. H. O'Grady, Silva Gadelica (London, 1892), i, 276-89, ii, 311-24. O'Grady used BL, Add. MS 18747, written by Patrick Lynch, Loughinisland, 1800, and a copy from Co. Cavan, written by the schoolmaster Silvester M'Gibney, 1847-48, which is now Cambridge University Library, MS 6561 (Padraig de Brún and Máire Herbert, Catalogue of Irish manuscripts in Cambridge libraries (Cambridge, 1986) xxvii, 83-85).

${ }^{56}$ Caoimhín Breatnach (ed.), Patronage, politics, and prose: Ceasacht inghine Guile, Sgéala muice Meic Dha Thó, Oidheadh Chuinn Chéadchathaigh (Maynooth, 1996), 44-63. In its very popular developed form, Ceisniomh inghine Guil is a text that Atkinson would certainly have found indecent (C. Breatnach, 'The transmission of Ceasacht inghine Guile: some observations', Éigse 32 (2000), 138-45). What Meyer had edited in his Hibernica Minora (Oxford, 1894), 65-69, was Erchoitmed ingine Gulide, a Middle Irish tale found in Bodl. MS Rawlinson B. 512. Its relationship to the early modern version of the story is discussed by C. Breatnach, 'Early modern Irish prose reconsidered: the case of Ceasacht inghine Guile', Ériu 42 (1991), 119-38.

${ }^{57}$ John O'Donovan, The Tribes of Ireland: a satire by Aengus O'Daly (Dublin, 1852), 28-32. John Whalley (1653-1724) was a publisher of almanacks in Dublin.
} 
'a very neatly-written fragment of a theological tract on death'. From the opening words which he quoted, the work can be identified as An Eagna Fhirinneach, one of four Irish translations of the late-seventeenth-century devotional work La vera Sapienza.$^{58}$ Three versions were never printed, and this is the fourth, translated by Seán Ó Conaill, which was printed at Cork, 1795, and again in 1813, from which Meyer noted the sixth of its seven considerazioni, Friday's meditation on Death. There is little chance that these fragments will now be traced, but Meyer has given us enough to have an idea what was lost. We shall never know how much more from that clothes-basket was swept downriver. Mr Gilbert, one must hope, took some comfort for his good deed in passing one fragment into institutional care. He certainly did not recover the price of his holiday.

The rescue of unwanted manuscripts, whether perceived as useless or merely as no longer required, was always haphazard. Those who did important work in this area sometimes did it to make the most of a market opportunity. This, I think, was the case with Messrs Hodges \& Smith between 1833 and 1843, and again with William Betham between 1840 and 1846. Much energy was wasted on commissioning new copies in the middle of the nineteenth century rather than in buying up surplus manuscripts from those to whom even a few shillings served a more immediate necessity. By the 1890s, Hyde was one of a few individuals who collected modern manuscripts. ${ }^{59}$ Others include James Goodman in Skibbereen and Hyde's friend David Comyn, a revivalist since the first days of the Society for the Preservation of the Irish Language.$^{60} \mathrm{By}$ this date, however, what was available was much diminished. The rhetoric was not really aimed at preserving manuscripts but at adding to the reasons for increased engagement with the survival of the language.

\footnotetext{
${ }^{58}$ Liam Ó hÉigearta, 'Iompó An Eagna Fhírinneach go Gaeilge', in Séimhfhear suairc. Aistí in ómós don Ollamh Breandán Ó Conchúir (Dingle, 2013), 602-24.

${ }^{59}$ His collection of seventy Irish manuscripts was bequeathed to University College Galway and is now held by the library of NUI Galway. Sixty-eight manuscripts were described in a catalogue made for Hyde himself by Áine de Búrca in 1926-27 (de Brún, Treoirliosta, 20, § 62), part of which has been typed, and these have brief entries in the NLI Sources database. Nine manuscripts are available via Irish Script on Screen. Information on the collection is not readily available in 2016. A few items have gone elsewhere.

${ }^{60}$ Comyn bequeathed thirty-six manuscripts to the National Library of Ireland in 1907, the first such accession since it was founded, now numbered G 182-G 217 (behind the Phillipps purchase of 1930), while Goodman's were bought in 1896 by his successor as professor at Trinity, James Murphy, and were bought by UCC in 1926, now catalogued by B. Ó Conchúir, Clár lámhscríbhinni Gaeilge Choláiste Ollscoile Chorcai: Cnuasach Ui Mhurchú (Dublin, 1991).
} 